\title{
CARE PROTOCOL FOR FINE-NEEDLE ASPIRATION BIOPSY OF BREAST AND THYROID
}

\author{
Ivone Rosini ${ }^{1}$, Nádia Chiodelli Salum ${ }^{2}$
}

\begin{abstract}
${ }^{1}$ M.Sc. in Nursing Care Management. Radiology Service Nurse of the University Hospital of the Universidade Federal de Santa Catarina (UFSC). Florianópolis, Santa Catarina, Brazil. E-mail: ivonerosini@gmail.com

2 Ph.D. in Nursing Philosophy. Professor of the Professional Master's Degree Course in Nursing Care Management of UFSC. Coordinator Nurse of the Nursing Research and Education Center of the University Hospital of UFSC. Florianópolis, Santa Catarina, Brazil. E-mail: nchiodelli@gmail.com
\end{abstract}

\begin{abstract}
This study had the aim of building a care protocol for fine-needle aspiration biopsy of breast and thyroid. Using a convergent-care type qualitative approach, it was developed in a teaching hospital in southern Brazil, between September 2010 and April 2011. The study participants were 88 patients and 20 professionals who work in the Radiology Service. The protocol was built in three stages: development of educational activities in the waiting room with the patients for the identification of doubts and anxieties in relation to the examination; meetings held with the professionals for the evaluation and validation of the protocol; and search for scientific evidence in data sources. The organization of data allowed to elaborate the flowchart of patient care and the care protocol, which was organized in sequential activities and included the executor, the activity and the scientific justification. The professionals expressed the importance of the protocol, which brings advantages for patient care, such as agility, organization and the humanization of the service.
\end{abstract}

DESCRIPTORS: Nursing assessment. Needle biopsy. Nursing.

\section{PROTOCOLO DE CUIDADOS PARA PUNÇÃO ASPIRATIVA POR AGULHA FINA DE MAMA E TIREOIDE}

RESUMO: O estudo objetivou construir um protocolo de cuidados para punção aspirativa por agulha fina de mama e tireoide. Com abordagem qualitativa, tipo convergente-assistencial, realizado em um hospital de ensino do Sul do Brasil, no período de setembro 2010 a abril de 2011. Participaram do estudo 88 clientes e 20 profissionais que atuam no Serviço de Radiologia. A construção do protocolo ocorreu em três etapas: realização de atividades educativas em sala de espera junto aos clientes para identificação de dúvidas e ansiedades quanto ao exame, encontros com os profissionais para avaliação e validação do protocolo; busca de evidências científicas em fonte de dados. A organização dos dados possibilitou elaborar o fluxograma de atendimento do cliente e o protocolo de cuidados, que foi organizado em atividades sequenciais constando do executor, atividade e justificativa científica. Os profissionais verbalizaram a importância do protocolo, trazendo benefícios para a assistência do cliente, como agilidade, organização e humanização do atendimento. DESCRITORES: Avaliação em enfermagem. Biopsia por agulha. Enfermagem.

\section{PROTOCOLO DE CUIDADOS PARA A LA PUNCIÓN ASPIRATIVA POR AGUJA FINA DE MAMA Y TIREÓIDES}

RESUMEN: El estudio objetivó construir un protocolo de cuidados para punción aspirativa con aguja fina de mama y tiroides. Con abordaje cualitativo, tipo convergente asistencial. el estudio fue realizado en un hospital de enseñanza en el sur de Brasil, en el periodo septiembre de 2010 a abril de 2011. Participaron del estudio 88 clientes y 20 profesionales que actúan en el Servicio de Radiología. La construcción del protocolo ocurrió en tres etapas: realización de actividades educativas em sala de espera junto a los clientes para identificación de dudas y ansiedades acerca del examen, encuentros con los profesionales para evaluación y validación del protocolo y búsqueda de evidencias científicas en las fuentes de datos. La organización de lós datos ha permitido la elaboración del organigrama de atendimiento del cliente y el protocolo de cuidados, que fue organizado en actividades secuenciales incluyendo el ejecutor, actividad y justificativa científica. Los profesionales indicaron la importancia del protocolo, trayendo beneficios para la asistencia del cliente, como la agilidad, organización y humanización del atendimiento.

DESCRIPTORES: Evaluación en enfermería. Biopsia por aguja. Enfermería. 


\section{INTRODUCTION}

The significant increase in new cases of cancer makes this disease a public health problem, demanding the creation of strategies that aim for better use of economic resources and technological advancements to grant citizens access to health measures that encourage the adoption of beneficial habits, in the search for quality of life in all stages of life. ${ }^{1-2}$

Studies on cancer show that public policies focused on actions of detection and early diagnosis achieved through the evaluation of the patient's complaints, physical examinations and complementary examinations, associated with technological innovation in the field of imaging, give opportunity to identify precancerous lesions or lesions in the early stages of the disease, increasing the possibilities of effectiveness in the treatment and cure of the disease. ${ }^{1,2}$

Aiming to define the diagnosis of the area altered by a tumor or cyst, the professed method is the biopsy of the lesion, which can be carried out through different techniques. Among these techniques there is the Fine-Needle Aspiration Biopsy (FNAB), which is noted as an efficient method in obtaining cytopathological material for support in the diagnosis of the biopsied lesion. ${ }^{1,3-5}$

The use of FNAB was first described in $1930,{ }^{6}$ when it was used for the diagnosis of breast tumors. Since then, many researchers took it upon themselves to employ, enhance and analyze the advantages and disadvantages of this method, making it popular by showing it as an initial diagnosis method for the cytological evaluation of tumors in general. . $^{3-5}$

FNAB is defined as the removal of material obtained by a transdermal needle, inserted in a specific region, in an organ or tissue, for cytopathological analysis. ${ }^{6}$ It became a basic diagnostic examination for the detection of breast and thyroid nodules because it is a minimally invasive procedure, inexpensive, easily executed, with rare complications and proven efficiency. The analysis of cytological material collected through FNAB allows for the distinction of tumors as "neoplastic and non-neoplastic", distinguishing neoplastic lesions as "benign or malignant". 7:298

The use of ultrasonography (USG) in conjunction with FNAB represents a large technological advance because it makes a real-time projection of the nodule and the needle possible. The needle progression toward the nodule is followed through the image projected in the USG machine screen, allowing the pathologist to visualize the position of the needle tip inside the lesion, enabling the aspiration of the nodule sample with the largest malignancy characteristic. ${ }^{8}$

Nevertheless, despite the simplicity of the technique, it causes apprehension in the patient as a result of fear of receiving an unfavorable diagnosis. The gaps existing in the guidance and information given to the patient hold an intersection space between nurse and patient, which gives the radiology service nurse an opportunity to establish an educational process. This environment is positive for the development of actions focused on health education based on technical knowledge, associated with the cultural context (beliefs and values) of the patients, aiming to share knowledge for the mobilization and adoption of measures in search of better health conditions and quality of life. ${ }^{9}$ Therefore, it represents a field of operation that the radiology service nurse must occupy to conduct their work.

Studies show that, despite the short time of stay of the patients in the sector, health education must be carried out, providing the information and guidance necessary for the execution of a quality examination. The development of the activities carried out in the waiting room is found to be a proper tool for this guidance, since patients are different each day. ${ }^{10}$

The radiology service encompasses the performance of many radiodiagnostic examinations. It is carried out by different professional categories, which do it according to their competences and attributions. According to this diversity of professionals, the standardization of actions is indicated to guide them in the execution of the procedure, for quality, risk-free care.

The standardization of conducts through protocols has been shown to be an important tool for quality patient care and team satisfaction, as well as for meeting the demands of institutional policies actions for quality and accreditation. ${ }^{11}$

The protocol is defined as a "normative instrument of the technical and social intervention process which guides professionals in the performance of their functions and is based on practical and scientific knowledge of healthcare work, according to each reality" ${ }^{12: 4}$ The use of protocols involves the decision making of many professionals and helps healthcare work, since they function as tools to guide the planned actions.

Protocol use is complex and relatively new in Brazil; however, it has gained relevance in nursing 
as a result of the need to standardize conducts with scientific basis. In this context, the protocol directs focus and establishes the actions that should be taken and the target demographic; defines and directs flow in all stages, from the start to the end of the process; correlates the professional responsible for each stage, stating the activity to be developed; lists the technical and technological resources for the development of actions; and presents the reasons for each developed action, based on the best scientific evidence, documents and institutional manuals to guide and support the activities.

Searching to improve and qualify the care for patients who look for the radiology service, as well as the legitimization of an educational space to be occupied by the nurse, looking to share the patients' expectations and wishes, as well as highlighting the orientations regarding the procedure they are going to go through, the aim of this study was to build a care protocol for fine-needle aspiration biopsy of breast and thyroid.

\section{METHOD}

This qualitative study used the Convergent Care Research (CCR) as method, whose main characteristic is keeping, during its whole process, a close relationship with practice aiming to propose solutions for existing problems and intercede in reality..$^{13}$ The CCR emerges from care, values reflection, knowing how to think and how to act, proposes intervention actions in practice and allows to execute them in the moment of data collection, making the interaction among those who participate in the process possible. For the development of the research process, the CCR establishes four phases: conception, instrumentation, exploration and interpretation. The conception phase covers the definition of the theme to be approached, the formulation of the research hypothesis, literature review and the definition of the theoretical framework. In the instrumentation phase, the location, the participants and the means to obtain and register research data are defined. The exploration phase defines the strategies and instruments that will be used to obtain information for the research. The analysis phase establishes the interpretation of the obtained information. ${ }^{13}$ The study was developed in the radiology service of a teaching hospital in southern Brazil. The institution has an agreement with the Santa Catarina State Health Department (SHD) to perform high complexity procedures, among which the USGguided FNAB of breast and thyroid. Therefore, ten weekly openings are available for the SHD and four openings for patients receiving care in the Teaching Hospital (TH), who are referred by physicians specialized in the fields of head/neck surgery, endocrinology and mastology.

The study participants were 88 patients and 20 professionals who work at the radiology service, including radiologists, pathologists, radiology and pathology residents, nursing technicians, a radiology technician, a receptionist and an administrative assistant.

Data were collected in the period between September, 2010 and April, 2011, in three stages. The first stage consisted of ten educational meetings in waiting rooms with the week patients for FNAB of breast and thyroid, aiming to investigate their expectations and doubts related to the examination; and post-examination semistructured interview, aiming to understand the potential and the limitations of the waiting room as an educational practice in the radiology service. In each meeting there were in average eight patients who accepted the invitation to take part in the educational activities in the waiting room and signed a Free and Informed Consent Form (FICF). The mobilization technique consisted of using different figures chosen at random: faces, landscapes, objects, flowers, among others that represent situations capable of causing feelings. They were placed randomly in the floor so that the group could observe them. Each patient was invited to choose from the figures those which best represented their feelings toward the examination. From that, the opportunity was given for each participant to express their feelings and perceptions, relating them to the chosen figure. The reflection activity carried out with the participants aimed at the manifestation of their concerns, doubts and wishes related to the procedure, as well as their background in the health system until that moment. The orientations offered information related to the goal of the examination, puncture site, care during and after the procedure, results and referrals. Since it is an interactive process, other doubts were expressed in the group, which were addressed as they appeared: the position on the gurney for the biopsy of the breast and thyroid, the importance of cooperating in the moment of the biopsy, the need for the biopsy for diagnostic confirmation of the nodule/cyst and the return to the physician after the release of the report.

In the moments before the end of the meeting the patients were informed that, after the ex- 
amination, the researcher would interview them with the objective of gaining knowledge about their perceptions regarding the health education procedure. It was a private moment, when the concerns that were not voiced before could be heard and registered. The interviews used the following questions: Could you describe how the examination was conducted? Could you tell me if the meeting we had before the examination helped you? In what aspects? What was missing?

The processed data identified in the waiting room activities were grouped in theme categories, showing the patients' main concerns and with the aim of guiding the preparation of the protocol.

The second stage was conducted in a participative, interdisciplinary manner through the execution of two meetings with the health team professionals from the radiology and the pathology services, who were invited to participate and signed a FICF. Both meetings were recorded and transcribed. A total of 20 professionals participated. The meetings were recorded with the professionals' consent and signed FICFs. In both meetings with the health team professionals there were representatives of all categories (a radiology physician from the radiology and the pathology services, a resident physician from the radiology service, nursing team from the radiology and the pathology services, an administrative assistant, a radiology technician and a receptionist).

The first meeting had the objective of stimulating interaction among the health team professionals, exposing the project, their perception regarding the performance of the examination and disclosure of the data obtained from the patients. The second meeting consisted of presenting and discussing the proposal for the protocol that was gathered, analyzed and validated by the health team. The suggested changes were registered by the researcher for later inclusion in the protocol.

The third stage was concomitant with the second. It consisted of the building of the "care protocol for fine-needle aspiration biopsy of breast and thyroid", based on three perspectives: information, questions and expectations collected from the patients in educational activities in waiting rooms; in the meetings with the health team professionals and scientific evidences found in literature. To support the theoretical aspect of the care actions a search for scientific evidence was conducted through review obtained from data sources: Virtual Health Library (VHL), 1030 articles; Cumulative Index to Nursing and Allied
Health Literature Publishing's Product \& Services (CINHAL-EBSCO), 377 articles and Scientific Electronic Library Online (SCIELO), 50 articles; using the descriptors: punção aspirativa por agulha fina, punção, câncer de mama, câncer de tireóide, enfermagem, fine-needle aspiration, biopsy, breast cancer, thyroid cancer, nursing. The inclusion criteria comprised online national and international full texts of randomized research with degrees of evidence from I to IV, ${ }^{14}$ published in the period between 2005 and 2011 and related to the theme, with the sample totaling 147 articles. Data were organized and categorized by the level of evidence found. ${ }^{14}$

Ethical aspects were observed as per the resolution $196 / 96,{ }^{15}$ with approval from the Research Ethics Committee of the UFSC, under the protocol number 1017/10.

\section{RESULTS AND DISCUSSION}

The protocol was prepared and validated with the group of professionals based on the researcher's immersion in the results from the meetings and interviews with the patients, from the discussions with the professionals and in the scientific evidences regarding the FNAB examination, defining two large categories: the patient's perception regarding the FNAB of breast and thyroid and the care protocol.

\section{Patient's perception regarding the examina- tion (FNAB)}

As observed, the main doubts and anxieties in relation to the FNAB of breast and thyroid are related to the objective of the examination, technique, site of the biopsy, number of nodules to be biopsied and number of biopsies in each nodule, need for surgery after the FNAB, need to use anesthesia for the procedure or lack thereof, reactions after the examination, result and referrals, possibility of a benign nodule becoming malignant and team that will perform the biopsy.

The concerns are mainly related to fear of the examination and its result. With the possibility of a positive result for malignancy, the human being faces a fearful event, of intense emotional vulnerability, both physically and socially. Similarly to any serious illness, cancer confronts the human being's whole context and causes reactions of disbelief, generating questions, which frequently takes one on a pilgrimage through the most reputed health services with the objective of confirming the initial 
result, as well as obtaining further explanations regarding the illness, treatment and prognosis. ${ }^{16}$

Misinformation regarding the examination can bring suffering to the patient and harm its performance. A study conducted in Taiwan showed that emotional informative support improves the psychological state of women who receive the information that they will be submitted to a breast biopsy. It indicates that the intervention conducted with the objective of supporting, giving the opportunity for active listening (face to face) and promoting follow up through the telephone can result in a smaller degree of anxiety in the group that received this attention, showing that, regardless from the result, support should be mantained. ${ }^{17}$

The doubts and concerns that were expressed were addressed in the waiting room and, afterwards, incorporated to the care protocol.

\section{Protocol preparation}

Provided with the information collected from the patients at hand, the health professionals' awareness was raised with the instigative question: if you were informed today by your physician that it would be necessary to perform a biopsy, how would you feel?

The professionals' reactions were similar to the ones collected from the patients, which shows the need for better explanation regarding the procedure by the professionals, as an attempt to lessen interference in the professional-patient relationship, which interferes in the performance of the procedure. It was concluded that communicational skills and active listening are necessary tools to provide emotional comfort that positively influence the patient's emotional adjustment to living through the process of losses and uncertainties inherent to illness and death. ${ }^{18-19}$ It was observed that the guidance offered in waiting rooms brought a positive effect and the reduction of anxiety during the procedure was clear, which made it possible for the patients to have a better participation during the examination, streamlining its performance. The assertive actions established in the waiting room were observed, appreciated and verbalized by the professionals who interact with the patients during the procedure, when they say: [...] I, who participate since the beginning of the FNAB performances, can vouch for the change that happened after the beginning of the meetings and guidance in the waiting room. The patients go in more peace- fully and with less fear, which makes the performance of the examination easier [...]. (P2). Similarly, the interviewed patients described how they arrived at the institution and made a comparison with the moment after the meeting: I was anxious and scared. I felt safe with them [referring to the team that performs the procedure] I was desperate during the lecture. When arriving there, I was confident [...] (P28).

This is how the articulation between the patients' speeches and the reflections of the professionals materialized, looking to delineate performance indicators that would bring the indicated situations together for the creation of new knowledge for care practice in the patient's treatment.

The collective preparation process makes it possible for the actors to see themselves as an active part in the performance of the actions, promoting shared responsabilization for the referrals for the resolution of the problems that can interfere in the chain of production of the patients' health care.

The meetings promoted between the professionals for the discussion of the protocol enabled the exchange of information, opinions and the debate regarding the suggestions submitted by the members of the health team. The team pointed to some submissions that were included: release form for post-biopsy result delivered to the patient at the moment of its liberation and supplying a light meal for the patients.

The preparation of a protocol must be conducted in a participative way among the members of the group responsible for the process that is being implemented, in association with the trinomial research, care and education, based on the best scientific evidence. ${ }^{20}$

To organize the flow of the care offered to patients who undergo a FNAB of breast and thyroid, a flowchart was created defining the whole path the patients go through from their arrival at the radiology service, through the health education moment, the biopsy, until their definitive discharge from the service.

The "flowchart descriptor" is a graphical representation showing the organization of the work processes that are interconnected, describing the actions, the flow and the actors involved in each of the stages, which must be fulfilled by the patient after their admission to the institution in search for care. ${ }^{21}$ The activities performed by each professional were identified by specific colors, to facilitate reading and comprehension of figure 1 . 


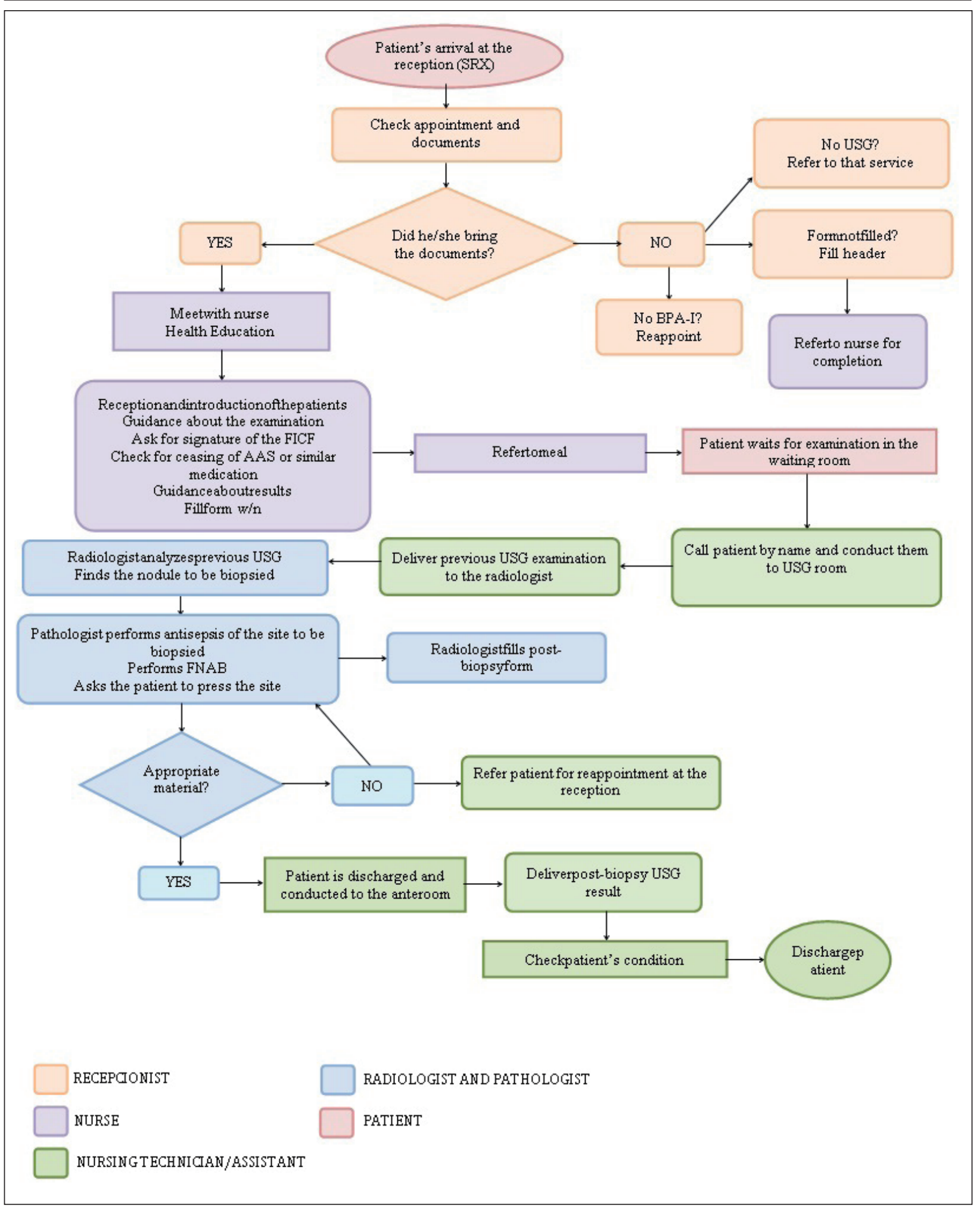

Figure 1 - Care flowchart for the patient submitted to FNAB of breast and thyroid

After the creation of the flowchart the proposal for the protocol was elaborated and organized to describe the actions to be performed in sequence, identifying the professional responsible for the execution of the action, the instruments and/or the necessary technology for performing the activity and the reason for that action based on scientific evidence identified in the integrative review, government or institutional regulations. The protocol was presented to the professionals, 
who voiced suggestions and conducts that should be part of it and later approval from the group as "Care protocol for fine-needle aspiration biopsy of breast and thyroid in the radiology service of the teaching hospital". There was an agreement about the need for periodical reviews and evaluations of its use.

The professionals recognized the importance of the protocol both for patient care as well as for agility, security, organization and humanization of the care.

\section{Care protocol for fine-needle aspiration biopsy of breast and thyroid in the radiology service of the teaching hospital}

The protocol is suggested as an instrument to structure, qualify, humanize, reduce harmful effects and ensure the quality of the care provided to the patient submitted to FNAB of breast and thyroid in the radiology service of the teaching hospital. It presents directions for actions to be taken in a methodical way, with the purpose of aiding the health interventions. ${ }^{12}$

Hence, the protocol established steps to be taken by the patients, defining and directing the flow in all stages, since their admission to the radiology service until their discharge. It also establishes the professionals' responsibilities for the defined actions and lists all the necessary resources for the examination performance. Each action was defined based on scientific evidence of levels I to IV, International Organization for Standardization (ISO 1998), government regulations, institutional and/or internal routines of the radiology and pathological anatomy service and the professionals' experience in the field.

Changes were proposed after the discussions with the health team, such as: preparation of a form for issuing post-biopsy results, placement on the gurney for the biopsy, location for recovery after the biopsy, use of ice after the biopsy, among others.

The protocol was organized in three areas that receive the patient during the execution of the procedure: patient reception area, health education area - waiting room and breast and thyroid examination area. For each of these areas, the actions were correlated to the professional who performs it, minutely described and scientifically justified.

The reception area involved the patient reception activities, delivery of the required documentation (forms, ultrasound exam, requisitions filling, the patient's electronic processing, delivery of the protocol for issuing the examination's results), and invitation to participate in educational activities in the waiting room.

The health education area - waiting room included the guidelines for the nurse regarding the examination: site of the biopsy, use of anesthesia and anticoagulant, placement in the gurney for breast biopsy (dorsal recumbent) and position for biopsy of the thyroid (dorsal recumbent with neck extension), number of nodules to be biopsied, postexamination care, results, need for surgery and professionals involved in the procedure, as well as the signature of the Free and Informed Consent Form, authorizing the procedure.

The procedure description area approached the actions ranging from the admission of the patient to the examination room, the description of the technique, the necessary materials and technology for the FNAB, stages for the performance of the biopsy of thyroid and breast respectively, post-biopsy care, and discharge after the biopsy.

\section{FINAL CONSIDERATIONS}

The preparation of the protocol made it possible for the radiology service nurse to effectively approach the patients scheduled for FNAB of breast and thyroid, using educational activities and guidance in the waiting room for that purpose. Thus, it aimed to promote freedom to express their feelings facing an invasive procedure for diagnostic purposes. Based on the verbalization of their concerns and needs, the necessities that demanded the development of care strategies became clear. When promoting the meetings in the waiting room, the nurse establishes an articulation between the dimensions of the nurse's practice that, when producing the care act, also educates.

In that sense, the importance of preparing the care protocol for patients submitted to FNAB of breast and thyroid becomes clear, as its intentionality brought about the act of rethinking the work process, identifying and understanding the barriers, reflecting and producing the legitimation of the acts to be performed by each of the members of the health team in the radiology service.

The participative way of preparing the protocol made it possible to build commitment between the care producers that, simultaneously, established educational processes. It allowed to direct the actions of each individual professional involved in the process, favored the involvement 
and gave opportunity for the shared responsibility relationship of the group when approaching the care for the patient submitted to FNAB of breast and thyroid.

This study significantly reveals the importance of the radiology service nursing professionals who, through educational actions developed with the patients, establish a new dynamic in care. It makes it possible for the patient to think about and interact with the process they will be submitted to, resizing their imaginary, thus making it possible to reduce anxiety and fear, enabling them to understand the stages that are to come.

A limitation of the study is that the educational actions for guidance should be extended for all patients submitted to invasive procedures in the radiology service, which is impractical because of the small number of nurses in the service.

\section{REFERENCES}

1. Organização Mundial de Saúde (OMS), Ministério da Saúde (BR). Execução da diretriz para a saúde da mama em países de baixa e média renda: Sinopse da Cúpula de 2007 sobre a Iniciativa Global para a Saúde da Mama. 2008 Out 15 [acesso 2011 Ago 26]; 113(8): Disponível em: www.femama.org.br/ingles/ arquivos/0.437461001286464199.pdf

2. Instituto Nacional de Câncer. ABC do câncer: abordagens básicas para o controle do câncer. Rio de Janeiro (RJ): INCA; 2011.

3. Nga ME, Kumarasinghe MP, Tie B, Sterrett GF, Wood B, Walsh J, et al. Experience with standardized thyroid fine-needle aspiration reporting categories: follow-up data from 529 cases with "indeterminate" or "atypical" reports. Cancer Cytopathol. 2010 Dec; 118(6):423-33.

4. Rosário PW, Purisch S. Ultrasonographic characteristics as a criterion for repeat cytology in benign thyroid nodules. Arq Bras Endocrinol Metab. 2010 Feb; 54(1):52-5.

5. Moon WJ, Baek JH, Jung SL, Kim DW, Kim EK, Kim, JY, et al. Ultrasonography and the ultrasoundbased management of thyroid nodules: consensus statement and recommendations. Korean J Radiol. 2011 Jan-Feb;12(1):1-14.

6. Kemp C, Lima GR. Punção por agulha fina. In: Piato S. Mastologia. São Paulo (SP): Roca; 1995. p. 59-62.

7. Buhler RB, Mattiola LR, Pinheiro JLG, Fava AS. Punção aspirativa por agulha fina em lesões de glândula parótida. Arq Int Otorrinolaringol. 2007 Jul-Set; 11(3):294-9.

8. Oliveira PRG. Carcinoma papilífero da tireóide: estudo comparativo entre os casos usuais e aqueles associados à tireoidite autoimune [tese]. São Paulo
(SP): Fundação Antônio Prudente, Curso de PósGraduação em Ciências; 2009.

9. Souza LB, Torres CA, Pinheiro PNC, Pinheiro AKB. Práticas de educação em saúde no Brasil: a atuação da enfermagem. Rev Enferm UERJ. 2010 Jan-Mar; 18(1):55-60.

10. Instituto Nacional de Câncer [página na internet]. Sistema de informação do controle do câncer de mama (SISMAMA): manual gerencial. Rio de Janeiro (RJ): INCA, 2009 [acesso 2011 Jun 28]. Disponível em: http:/ / www.redecancer.org.br/wps/wcm/ connect/d19dd6804d9c1751bed5bfca6e73abae/Manual_Gerencial+SISMAMA.pdf?MOD=AJPERES

11. Guerreiro GP, Beccaria LM, Trevizan MA. Procedimento operacional padrão: utilização na assistência de enfermagem em serviços hospitalares. Rev Latino-Am Enferm [online]. 2008 [acesso 2011 Ago 23]; 16(6). Disponível em: http:/ / www.scielo. br/pdf/rlae/v16n6/05.pdf

12. Conselho Regional de Enfermagem de Minas Gerais [página na internet]. Câmara Técnica da Atenção Básica, COREn/MG: protocolos gerenciais da atenção básica. Belo Horizonte (MG): COREN/MG, 2009 [acesso 2011 Ago 20]. Disponível em: http:/ / www.corenmg.gov.br/sistemas/app/web200812/ docs/anexos/conteudo_dinamico/Apresentacao_ Protocolos_Assistenciais_Rosana_Paes.pdf

13. Trentini M, Paim L. Pesquisa convergenteassistencial: um desenho que une o que fazer e o pensar na prática assistencial em saúde-enfermagem. $2^{a}$ ed. Florianópolis (SC): Insular; 2004.

14. Williams TA, Leslie GD. A review of the nursingcare of enteral feeding tubes in critically ill adults: part I. Intensive Crit Care Nurs. 2004 Dec; 20(6):330-43.

15. Ministério da Saúde (BR). Resolução n. 196, de 10 de outubro de 1996. Estabelece critérios sobre Pesquisa Envolvendo Seres Humanos. Brasília (DF): Conselho Nacional de Saúde; 1996 [acesso 2011 Jul 14]. Disponível em http:/ / conselho.saude.gov.br/ Resolucoes/1996/Reso196.doc

16. Salci MA, Marcon SS. Itinerário percorrido pelas mulheres na descoberta do câncer. Esc Anna Nery Rev Enferm [online]. 2009 [acesso 2011 Ago 23]; 13(3). Disponível em: http:/ / www.scielo.br/pdf/ ean/v13n3/v13n3a15.pdf

17. Liao MN, Chen PL, Chen MF, Chen SC. Effect of supportive care on the anxiety of women with suspected breast cancer. J Adv Nurs. 2010 Jan; 66(1):49-59.

18. Araújo MMT, Silva MJP. O conhecimento de estratégias de comunicação no atendimento à dimensão emocional em cuidados paliativos. Texto Contexto Enferm. [online]. 2012 Jan-Mar [acesso 2012 Abr 15], 21(1):121-9.

19. Muniz RM, Zago MMF, Schwatz E. As teias da sobrevivência oncológica: com a vida de novo. Texto Contexto Enferm. 2009 Jan-Mar; 18(1):25-32. 
20. Zylbersztejn J, Hagemann LL, Fritzen R. Protocolos clínicos e sua interface com ensino, pesquisa assistência e política de gestão [monografia especialização em Gestão Hospitalar]. Porto Alegre (RS): Fundação Oswaldo Cruz, Escola Nacional de Saúde Pública; 2006 [acesso 2011 Ago 29]. Disponível em: www2.ghc.com.br/gepnet/docscursos/ gestao/gestaojaco.pdf

21. Malta DC, Ferreira LM, Reis AT, Merhy EE. Mudando o processo de trabalho na rede pública: alguns resultados da experiência em Belo Horizonte. Saúde Debate. 2000; 24:21-34. 